152

Received: July 10, 2012

Accepted: November 23, 2012

\title{
EFFECTS OF AROMATIC PLANTS ON RUMEN FERMENTATION
}

\author{
Duygu Budak ${ }^{1}$, Aydan Yılmaz \\ ${ }^{1}$ Aksaray University, Aksaray Vocational High School, Aksaray, Turkey \\ ${ }^{2}$ Ankara University, Faculty of Agriculture, Department of Animal Science, Ankara, Turkey \\ budakduygu@hotmail.com
}

\begin{abstract}
Taking rumen conditions under control has great importance for productivity and animal health. By using aromatic plants it is aimed to provide rumen manipulation for making modifications in the activities of rumen microorganisms, optimizing the nutritional value of the feeds, improving the efficiency of the fermentation. The limitation of use of antibiotics in animal nutrition directed scientists to make studies about the use of alternative antimicrobial substances. For this aim, aromatic plants and volatile oils produced from them have been used. In this review; aromatic plants owning antimicrobial and antioxidant properties and their efficiency mechanisms, chemical compositions, volatile oils and their properties, utilization of aromatic plants in ruminant nutrition and its effects on rumen fermentation were summarized. In general evaluation of the performed researches it was concluded that the antimicrobial property of aromatic plants contributes to the increase of protozoa numbers, utilization of aromatic plants and the volatile oils produced from them with regard to their active substances and their limited utilization which improves the rumen fermentation.
\end{abstract}

Key words: aromatic plants; rumen fermentation; volatile oils; antimicrobial; antioxidant

\section{ЕФЕКТИ НА АРОМАТИЧНИ РАСТЕНИЈА ВРЗ ФЕРМЕНТАЦИЈАТА ВО РУМЕНОТ}

\begin{abstract}
Контролата на условите во руменот има големо значење за продуктивноста и здравјето на животните. Со користење на ароматични растенија се обезбедува модификација на активностите на руминалните микроорганизми, оптимизирање на нутритивната вредност на храната и подобрување на ефикасноста на ферментацијата. Ограничувањето на употребата на антибиотици во исхраната на животните ги насочи научниците кон истражување на употреба на алтернативни антимикробни супстанции. За оваа цел се користени ароматични растенија и етерични масла произведени од нив. Во овој труд беа испитувани ароматичните растенија кои имаат антимикробни и антиоксидантни својства, механизми, хемиски состав, етеричните масла и нивните својства, како и користењето на ароматичните растенија во исхраната на преживарите и нивните ефекти врз ферментацијата во руменот. Општ заклучок е дека антимикробните својства на ароматичните растенија придонесуваат за зголемување на бројот на протозои, а со користење на ароматичните растенија и етеричните масла произведени од нив, со оглед на нивните активни супстанции и нивната ограничена искористеност, се подобрува ферментацијата во руменот.
\end{abstract}

Клучни зборови: ароматични растенија; ферментација во румен; етерични масла; антимикробни; антиоксидантни

\section{INTRODUCTION}

During the process of rumen fermentation in ruminants, energy and protein losses that limit feed efficiency occur. As converted to the methane gas during the process of rumen fermentation, approximately 12 per cent of gross energy of feed is released into the atmosphere through belching (ructus). On the other hand, the excreted urea consists of the protein in feed that the animal cannot make use of and corresponds to the 20 to 25 per cent of the nitrogen taken in from the feed. In the formation of such losses, the gram-positive bacteria in rumen, which produce more hydrogen, methane, ammonia and lactic acid, play a major role compared to the gram-negative bacteria (Görgülü 
2004, Calsamiglia et al., 2007, Hart et al., 2007, Demirtaş et al., 2011). It is stated that in order to optimize the nutritive value of the feed by suppressing the gram positives, and improve the efficiency of fermentation and the use of substrate, rumen can be manipulated and rumen manipulation strategies can be implemented indirectly with ration manipulation (McIntosh, 2003; Wanapat, 2008a). Following the prohibition of antibiotic ionophores that regulate rumen fermentation, the use of volatile oils in the regulation of rumen fermentation has become a current issue based on the idea that volatile oils can be an alternative to antibiotics because of their antimicrobial properties (Wallace, 2004; Tekeli et al., 2007; Canbolat et al., 2011). Therefore, in recent years, aromatic plants and volatile oils produced from them are one of the most important sources of natural additives (Önenç and Akkan, 2008). Among aromatic plants, are those contain volatile oils and they are called essential oil crops which have an important role. In this review, some researches on aromatic plants owning antimicrobial and antioxidant properties and their efficiency mechanisms, chemical compositions, volatile oils and their properties, importance of utilization of aromatic plants in ruminant nutrition and its effects on rumen fermentation were addressed.

\section{AROMATIC PLANTS AND THEIR EFFI- CIENCY MECHANISMS}

The term aromatic plants is used to indicate the plants that produce various fractions in order to reproduce, sustain their lives and protect themselves. Such fractions are extracted from the plants via steam distillation or the squeezing method. These are often phenol compounds inherent in volatile oils, with anti-oxidative, fungicidal, and antimicrobial effects (Ilçım et al. 1998, Toroğlu and Çenet, 2006; Yeşilbağ, 2007). Rates of active substances in aromatic plants vary with respect to the source of the plant. Each aromatic plant becomes effective with the active chemical compounds in its seed, fruit, leaves or roots (Table 1).

Table 1

Aromatic plants, their used parts, active substances and mode of action.

\begin{tabular}{llll}
\hline \hline Name of the plant & Used parts & Active substances & Mode of action \\
\hline Cumin & Seed & Cuminaldehyde & Digestive stimulant \\
Anise & Seed & Anethole & \\
Black pepper & Fruit & Piperine & \\
Chaste & Fruit & Limonene & \\
Paprika & Fruit & Capsaicin & \\
Ginger & Rhizome & Zingorole & \\
\hline Horseradish & Root & Allylisothiocyanate & Appetite enhancer \\
Celery & Leaf & Phtalides & Appetite enhancer, digestive stimulant \\
Coriander & Leaf, seed & Linalol & \\
\hline Garlic & Bulb & Alicin & Digestive stimulant, antiseptic \\
Rosemary & Leaf & Cineole & \\
Sage & Leaf & Cineole & \\
\hline Fennel & Seed & Trans-anethol & Digestive stimulant, antioxidant \\
\hline Carnation & Flower & Eugenol & Appetite enhancer, digestive stimulant, antiseptic \\
Cinnamon & Crust & Cinnamaldehyde & \\
Parsley & Leaf & Apiol & \\
Laurels & Leaf & Cineole & \\
Mint & Leaf & Menthol & \\
\hline Thyme & All plant & Thymol, Carvacrol & Digestive stimulant, antiseptic, antioxidant \\
\hline Mustard & Seed & Allylisothiocyanate & Appetite enhancer, digestive stimulant, antioxidant \\
\hline \hline
\end{tabular}

(Özgüven and Kırıcı, 1998; Güler and Dalkılıç, 2005; Önenç and Açıkgöz, 2005; Altundağ and Aslım, 2005; Calsamiglia et al., 2007; Önenç, 2011; Sanlı et al., 2008; Şengezer and Güngör, 2008; Uzun et al., 2010; Demirtaş et al. 2011) 
Aromatic plants, changing the sensory characteristics of feed such as taste and odor, manipulate feed consumption and feed palatability, and as they stimulate digestion enzymes and secretions, help better digestion and absorption of nutrients (S. Ando et al., 2003; Hosoda et al., 2005). This particular positive effect develops by the increases in salvation, gastric acid salvation and certain digestive enzymes (Yeşilbağ, 2007). Additionally, as a result of the chemicals in their structure, their relaxing, antimicrobial, fungicidal and anti-oxidative effects, and their brain stimulating, sedative and antidepressant effects relate to increased cerebral blood flow. The most important property of aromatic plants and their extracts such as rosemary and thyme is that they have antioxidant activity (Demirtaş et al., 2011; Altundağ and Aslım, 2005). By neutralizing free radicals which are triggered by exogenous factors such as ultraviolet rays, radiation, infections and stress, and cause oxidation, aromatic plants allow the body to protect itself from such substances or renew itself through antioxidants (Svoboda and Hampson, 1999). By means of the phenol compounds they contain, their growth factor does not constitute a bacterial resistance compared with antibiotics, and they lead to bacteriolysis directly affecting the cell wall (Yeșilbağ, 2007).

\section{CHEMICAL COMPOSITIONS OF AROMATIC PLANTS}

Volatile compounds which produce aroma, and non-volatile flavor and color pigments constitute the main characteristic of the aromatic plants which consist of different chemical compositions (Gill, 1999) such as:

Water; unless freshly consumed, the water content of spices is low. Following desiccation, the water content is between 5 to 12 per cent.

Carbohydrates; spices mostly contain glucose, fructose, sucrose, maltose and raffinose. Depending on the type of spice, the amount of starch varies between 0.5 per cent.

Nitrogenous substance; proteins do not contribute to aroma significantly. The heat treatment gives some sensory properties.

Lipids; lipids such as fixed oils, phospholipids, sterols and waxes are found particularly in the fruits and seeds of aromatic plants.

Glycosides; they affect the characteristics of aromatic plants such as taste, smell and color.
Alkaloids; most of the alkaloids taste bitter and are colorless, and others have a strong odor.

Tannins; some aromatic plant species contain tannins, and as well as the antimicrobial and antioxidant effects, they give the plant its acrid taste.

Organic acids; Malic, citric, tartaric and succinic acid are the most common organic acids.

Vitamins; most of the aromatic plants plays an important role in nutrition with regards to vitamins. Especially, freshly consumed leaves are rich in vitamin $\mathrm{C}$.

Minerals; being in higher levels in the leaves, they contain approximately 3 to 10 per cent of ash.

Antimicrobials; volatile oils found in most of the aromatic plants (especially in rosemary, thyme, mustard, cloves and cinnamon) show antimicrobial effects.

Volatile oils; they can be found in almost all aromatic plants.

\section{VOLATILE OILS AND THEIR PROPERTIES}

Volatile oils are oleaginous mixtures which can be produced from plants usually by means of distillation. They are generally in liquid form at room temperature and can be washed away with the water vapor (Adiyaman and Ayhan, 2010; Önenç, 2011). It is widely known that the antimicrobial activity of plant extracts results from the secondary plant components such as terpenoids (thymol, carvone, carvacrol, terpinene-4-ol) and phenylpropanoids (cinnamaldehyde, eugenol, anethole) which can be found in most of the plant volatile oils (Busquet et al., 2005a). The antioxidant activity of aromatic plants is closely related to the amount of the essential oil in the quality of secondary metabolite in their structures. The amount of such components varies in each plant due to individual (morphogenetic and ecologic factors), genetic and genome differences (Skerget et al., 2005; Çalıkoğlu et al., 2006; Evren and Tekgüler, 2011) and they can be found in most of the plants at certain amounts because of the protective role they play against the attacks by bacteria, fungi or insects. They mostly consist of cyclic hydrocarbons and aldehyde or ester derivatives of cyclic hydrocarbons (Wallace et al., 2002).

The basic mechanism of action of volatile oils is the inhibition of production of ammonia from amino acids. This mechanism of action was formed by means of the effects of volatile oils on the bacteria that can produce high levels of ammonia (Öztürk et al., 2001; Molero et al., 2004). The 
capability of the bacteria that can produce high levels of ammonia in generation of ammonia from amino acids is very high and even the smallest reduction in the rate of generation of ammonia can be beneficial in terms of nutrition (Wallace et al., 2002).

\section{THE IMPORTANCE OF UTILIZING AROMATIC PLANTS IN RUMINANT NUTRITION}

In rumen, a relatively high amount of energy and protein is lost in the form of methane and ammonia nitrogen as a consequence of microbial fermentation (NRC, 2001). During the anaerobic fermentation process of soluble and structural carbohydrates, methane is produced via methanogenesis (methane formation) by the microorganisms and this leads to the energy loss (Calsamiglia et al., 2007; Benchaar et al., 2008). In order to reduce this loss, it is required for an increase in propionate or butyrate through the bacterial transfer of hydrogen (Dominguez Bello and Escobar, 1997; Kung et al., 2008). In general, an increase in propionic acid can cause a reduction between 4 to 31 per cent in the amount of methane produced in rumen (Güçlü and Kara, 2009). It is possible to find evidence in most of the researches conducted supporting this conclusion. On the other hand, fermentation products generated by the microorganisms cause the release of contaminants onto the environment (Calsamiglia et al., 2007). Given to their nitrogen bonding and ammonia controlling properties, extracts of aromatic plants also facilitate the formation of a cleaner and healthier environment (Tekeli et al., 2007). By the use of crude protein resources with low degradability in rumen or through the modification of rumen microbial activity with plant extracts, microbial degradation of crude protein that belongs to the ration can be controlled. It is indicated that in this way, the efficiency of use of $\mathrm{N}$ was improved and $\mathrm{N}$ losses were significantly reduced (Cardozo et al., 2004; Calsamiglia et al., 2007; Benchaar et al., 2008). The extracts of plants form a complex with the proteins of the ration and protect them from the microbial fermentation. Those which contain saponin in particular have a strong antiprotozoal activity when used in a limited amount (Wei-Lian et al., 2000, Güçlü and Kara, 2009).

The structure of ration consumed determines the number of bacteria and protozoa in rumen and depending on that, ratio of volatile fatty acids can vary (Demirtaş et al., 2011). All protozoa store starch-like carbohydrates, keep the speed of bacterial multiplication under control by reducing the amount of substrate and ensure the stabilization of the rumen environment. In the presence of protozoa in rumen, the total amount of volatile fatty acids and the amount of rumen ammonia-N are higher (Öztürk et al., 2001; Görgülü, 2004). In most of the researches conducted, the scientists have reported that the extracts of plants have an impact on the number of protozoa.

Secondary components, found in the structure of most of the plants such as phenolic compounds, volatile oils and sarsaponin, can be used against the gram positive and gram negative bacteria as natural additives in animal nutrition (Hart et al., 2007; Wallace, 2004; Benchaar et al., 2008). Thus, reduction in rumen microbial activity and ration fermentability can be achieved (Cardozo et al., 2004).

\section{RESEARCH ON THE EFFECTS OF AROMATIC PLANTS ON RUMEN FERMENTATION}

In one of the recent studies conducted with volatile oils, it is confirmed that the mixture including cinnamaldehyde as the main component has an antibacterial activity against escherichia coli, enterococcus faecalis, staphylococcus aureas, salmonalla $s p$ and vibrio parahemolyticus (Wallace et al., 2002).

It is reported that thymol inhibited the gram positive and gram negative bacteria with oral selenomonads and streptocci; and some volatile oils modified the concentrations of rumen volatile fatty acids and reduced the speed of amino acid deamination, the speed of ammonia production and the number of bacteria that can produce high levels of ammonia (Evans and Martin, 2000). It is stated that as the essential oil, cinnamon extract of which the active ingredient is eugenol showed antimicrobial activity over the gram positive and gram negative bacteria given to its phenolic compounds (Fraser et al., 2007). It is presented that a commercial essential oil mixture containing thymol, eugenol, vanillin and limonene as the active substances inhibited the rate of deamination in rumen, and that manipulation of rumen fermentation could be ensured by suppressing certain rumen microorganisms (McIntosh et al., 2003). According to a similar research, it is indicated that a mixture of essential oil with thymol, guajacol and limonene as 
the active substances tended to increase the total volatile fatty acids concentration (Newbolda et al., 2004). It is reported that ammonia-nitrogen $\left(\mathrm{NH}_{3}-\right.$ $\mathrm{N})$ concentration of the extracts of plants could affect the rates of propionate and butyrate with the ruminal $\mathrm{pH}$ and the numbers of protozoa (S. Ando et al., 2003; Busquet et al., 2005b; Öztürk et al., 2012). Additionally, it is asserted that extracts of mint (Hosoda et al., 2005), carnation and garlic (Patra and Kamra, 2006) reduce the energy loss caused by methane generation and methane. According to some scientists, it is revealed that while $\mathrm{NH}_{3}-\mathrm{N}$ concentration decreased parallel to the increase in essential oil percentage, microbial protein production increased and a significant rise in the number of protozoa was achieved (Sallam et al., 2009a; Sallam et al., 2009b). Therefore, it is confirmed that natural plant extracts can be utilized in selective regulation of certain microbial types and hence modification in rumen microbial activity can be delivered (Cardozo et al., 2004; Benchaar et al., 2007).

According to the recent research conducted, it is concluded that aromatic plants and volatile oils produced from them facilitate rumen fermentation with regard to the active substances in their content and limited utilization (Cardozo et al., 2005; Castillejos et al., 2006; Sallam et al., 2009b; Canbolat et al., 2010; Kongmun et al., 2010; Canbolat et al., 2011; Taghavi et al., 2011).

\section{CONCLUSION}

It is concluded that the use of aromatic plant extracts:

- facilitates rumen fermentation with regard to the active substance and limited utilization,

- reduces energy loss caused by methane,

- reduces the release of methane into the atmosphere,

- and affects the number of protozoa.

\section{REFERENCES}

[1] Adiyaman E., Ayhan V. (2010): Etlik piliçlerin beslenmesinde aromatik bitkilerin kullanımı. Hayvansal Üretim Derg. 51 (1), 57-63.

[2] Altundağ Ş., Aslim B. (2005): Kekiğin bazı bitki patojeni bakteriler üzerine antimikrobiyal etkisi. Orlab On-Line Mikr. Derg. 3 (7), 12-14.

[3] Benchaar C., Chaves A. V., Fraser G. V., Wang Y., Beauchemin K. A., Mcallister T. A. (2007). Effects of essential oils and their components on in vitro rumen microbial fermentation. Dairy and Swine Research, 923 p., Alberta, Canada.
[4] Benchaar C., Calsamiglia S., Chaves A., Fraser G. R., Colombatto D., Mcallister T. A. Beauchemin K. A. (2008). A review of plant-derived essential oils in ruminant nutrition and production. Dairy and Swine Research, 924 p., Alberta, Canada.

[5] Busquet M., Calsamiglia S., Ferret A., Kamel C. (2005a): Screening for effects of plant extracts and active coumpounds of plants on dairy cattle rumen microbial fermentation in a continuous. Anim. Feed Sci. and Tech., 123: 597-613.

[6] Busquet M., Calsamiglia S., Ferret A., Cardozo P. W., Kamel C. (2005b): Effects of cinnamaldehyde and garlic oil on rumen microbial fermentation in a dual flow continuous culture. J. Dairy Sci., 88, 2508-2516.

[7] Calsamiglia S., Busquet M., Cardozo P. W., Castillejos L., Ferret A., (2007): Invited review: Essential oils as modifiers of rumen microbial fermentation. J. Dairy Sci., 90 : 2580-2595.

[8] Canbolat Ö., Karaman Ş., Filya İ. (2010): Farklı kekik yağı dozlarının mısır silajının sindirimi ve rumen fermantasyonu üzerine etkileri. Kafkas Ünv. Vet. Fak. Derg., 16 (6), 933-939.

[9] Canbolat Ö., Kalkan H., Karaman Ş., Filya İ. (2011): Esansiyel yağların sindirim, rumen fermantasyonu ve mikrobiyal protein üretimi üzerine etkileri. Kafkas Ünv. Vet. Fak. Derg., 17 (4), 557-565.

[10] Cardozo P. W., Calsamiglia S., Ferret A, Kamel C. (2004): Effects of natural plant extracts on ruminal protein degradation and fermentation profiles in continuous culture. J. Anim. Sci., 82, 3230-3236.

[11] Cardozo P. W., Calsamiglia S., Ferret A, Kamel C. (2005): Screening for the effects of natural plant extracts at different $\mathrm{ph}$ on in vitro rumen microbial fermentation of a high-concentrate diet for beef cattle. J. Anim. Sci., $83,2572-2579$.

[12] Castillejos L., Calsamiglia S., Ferret A. (2006): Effect of essential oil active compounds on rumen microbial fermentation and nutrient flow in in vitro systems. J. Dairy Sci., 89, 2649-2658.

[13] Çalikoğlu E., Mustafa K., Bayrak A. (2006): Uçucu yağ nedir, nasıl üretilir ve türkiye'deki durumuna genel bir bakış. Türkiye 9. Glda Kongresi: 24-26 Mayıs, Bolu.

[14] Demirtaş A., Öztürk H., Pişkin İ., Demirkiran D., Salgirli Y. (2011): Biberiye ve adaçayı ekstraktlarının ruminal fermantasyon üzerine etkilerinin rumen simülasyon tekniği (RUSITEC) ile araştırılması. İstanbul Ünv. Vet. Fak. Derg., 37 (2), 127-134.

[15] Dominguez Bello M. G., Escobar A. (1997): Rumen manipulation for the improved utilization of tropical forages. Anim. Feed Sci. and Tech., 69, 91-102.

[16] Evans J. D., Martin S. A. (2000): Effects of thymol on ruminal microorganism. Curr. Micr., 41, 336-340.

[17] Evren M., Tekgüler B. (2011): Uçucu yağların antimikrobiyel özellikleri. orlab on-line mikr. Derg., 9 (3), 28-40.

[18] Fraser G., Chaves A., Wang Y., Mcallister T., Beauchemin K., Benchaar C. (2007): Assessment of the effects of cinnamon leaf oil on rumen microbial fermentation using two continuous culture systems. J. Dairy Sci., 90, 2315-2328.

[19] Gill C. (1999): Herbs and plant extracts as growth enhancers. Feed Int., 20, 20-23.

[20] Görgülü M. (2004): Sindirim sistemi ve besleme. Çukurova ünv. Ziraat Fak. Yayını, 75 s., Adana.

[21] Güçlü B., Kara K. (2009): Ruminant beslemede alternatif yem katk1 maddelerinin kullanımı:1. probiyotik, Prebiyotik ve Enzim. Erciyes Ünv. Vet. Fak. Derg., 6 (1), 65-75. 
[22] Güler T., Dalkiliç B. (2005): Aromatik bitkilerin organik (ekolojik) hayvancılıkta kullanım imkanı. Firat Ünv. Vet. Fak., Hay. Bes. ve Besl. Hast. Anabilim Dalı, Doğu Anadolu Böl. Araştırmaları, Elazı $\breve{g}$.

[23] Hart K. J., Y'ÃNez-Ruiz D., Duval S., Mcewan N., Newbold C. (2007): Plant extracts to manipulate rumen fermentation. Animal Feed Sci. and Tech., 23, 3, UK.

[24] Hosoda K., Nishida T., Park W. Y., Eruden B. (2005): Influence of Mentha×piperita L. (peppermint) Supplementation on nutrient digestibility and energy metabolism in lactating dairy cows. Asian-Aust. J. Anim. Sci., 18 (12): $1721-1726$.

[25] Ilçim A., Diğrak M., Bağci E., (1998): Bazı bitki ekstraktlarının antimikrobiyal etkilerinin araştırılması. TÜBITAK yayını, 22, 119-125.

[26] Kongmun P., Wanapat M., Pakdee P., Navanukraw C. (2010): Effect of coconut oil and garlic powder on in vitro fermentation using gas production technique. Livestock Sci., 127, 38-44.

[27] Kung J., Williams P, Schmidt R. J., Hu W., (2008): A blend of essential plant oils used as an additive to alter silage fermentation or used as a feed additive for lactating dairy cows. J. Dairy Sci., 91, 4793-4800.

[28] Mcintosh F. M., Williams P., Losa R., Wallace R. J., Beever D., Newbold C. J. (2003): Effects of essential oils on ruminal microorganisms and their protein metabolism. Appl. Environ. Micr., 69 (8), 5011.

[29] Molero R., Ibars S., Calsamiglia A. Ferret, R. Losa (2004). Effects of a spesific blend of essential oil compounds on dry matter and crude protein degrability in heifers fed diets with different forage to contrate rations. Anim. Feed Sci. and Tech., 114, 91-104.

[30] Newbolda C., Mcintosh F., Williams P., Losac, R., Wallace J. (2004): Effects of a Specific Blend of Essential oil Compounds on Rumen Fermentation. Rowett Research Institute, Greenburn Road, Bucksburn, Aberdeen AB219SB, UK.

[31] NRC (2001). Nutrients requirements of dairy cattle. 7 th Rev. Ed. Natl. Acad. Press, Washington, D.C.

[32] Önenç S., Açikgöz Z. (2005): Aromatik bitkilerin hayvansal ürünlerde antioksidan etkileri. Ege Ünv. Ziraat Fak. Hayvansal Üretim, 46 (1): 50-55, Bornova, İzmir.

[33] Önenç S., Akkan S., (2008): Bazı aromatik bitkilerin invitro rumen fermantasyonu üzerine etkileri. Ege Ünv. Fen Bilimleri Enstitüsü. Doktora Tezi. Bornova- İzmir.

[34] Önenç S. (2011): Aromatik bitkilerin rumen fermantasyonu üzerine etkileri. Çukurova Ünv., 7. Ulusal Zootekni Bilim Kongre Kitabl, 183 s., Adana.

[35] Özgüven M., Kirici S. (1998): Farklı ekolojilerde nane (mentha) türlerinin verim ile uçucu yağ oran ve bileşenlerinin araştırılması. Tr. J. of Agriculture and Forestry, TÜBITAK yayını, 23, 465-472.

[36] Öztürk D., Kamalak A., Işik S. Ş. (2001): Rumende uçucu yağ asitleri ile protein üretimi ve ölçülmesi. Fen ve Mühendislik Derg., 4 (1), 158.

[37] Öztürk H., Demirtaş A., Salgirli Y., Pekcan M., Emre B., Fidanci U. R. (2012): Effects of olive leaf extrakt on rumen Microbial Fermentation in İn vitro Semi-continuous Culture System (RUSITEC). Ankara Ünv. Vet. Fak. Derg., 59, $17-21$.

[38] Patra A., Kamra D. (2006): Effect of spices on rumen fermentation, methanogenesis and protozoa counts in in vitro gas production test. International Congress Series: 1293: 176-179.
[39] Sallam S., Bueno I., Brigide P., Godoy P., Vitti D., Abdalla A. (2009a): Investigation of potential new opportunities for plant extracts on rumen microbial fermentation in vitro. Options Mediterraneennes, $\mathbf{A} /$ no. 85, Brazil.

[40] Sallam S., Bueno I., Brigide P., Godoy P., Vitti D., Abdalla A. (2009b): Efficacy of eucalyptus oil on in vitro ruminal fermantation and methane production. Option Mediterraneennes, A/ no. 85, Brazil.

[41] Ando S. N., İshida M., Hosoda K., Bayaru E. (2003). Effect of peppermint feeding on the digestibility, ruminal fermentation and protozoa. Livestock Production Sci., 82: $245-248$.

[42] Sanli A., Karadoğan T., Baydar H. (2008): Doğal olarak yetişen tatl rezene (Foeniculum vulgare Mill. var.dulce)' nin farklı büyüme ve gelişme dönemlerinde uçucu yağ miktarı ile bileşenlerinin belirlenmesi. Süleyman Demirel Ünv. Ziraat Fak. Derg. 3 (2), 17-22.

[43] Skerget M., Kotnik P., Hadolin M., Hras A. R., Simonic M., Knez Z. (2005): Phenols, proanthocyanidis, flavones and flavonols in some plant materials and their antioxidant activities. Food Chemistry, 89, 191-198.

[44] Svoboda K. P., Hampson J. B. (1999): Bioactivity of Essential oils of Selected Temperate Aromatic plants: antibacterial, antioxidant, antiinflammatory and other related pharmacological activities. Plant Biology Department, SAC Auchincruive, Ayr, Scotland, UK., KA6 5HW.

[45] Şengezer E., Güngör T. (2008): Esansiyel yağlar ve hayvanlar üzerindeki etkileri. Kırıkkale Ünv. Vet. Fak. Lalahan Araşt. Enst. Derg., 48 (2), 101-110.

[46] Taghavi N., Alipour D., Goudarzi M., Zamani P. (2011): Dose response to carvone rich essential oils of spearmint (Mentha spicata $L$.): İn vitro ruminal fermentation kinetics and digestibility. J. Agr. Sci. Tech., 13, 1013-1020.

[47] Tekeli A., Çelik L., Kutlu H. R. (2007): Plant extracts; a new rumen moderator in ruminant diets. $J$. of Tekirdag Agricultural Faculty, 4 (1).

[48] Toroğlu S., Çenet M. (2006): Tedavi amaçlı kullanılan bazı bitkilerin kullanım alanları ve antimikrobiyal aktivitelerinin belirlenmesi için kullanılan metodlar. K.S.Ü. Fen ve Müh. Derg., 9 (2).

[49] Uzun A., Özçelik H., Özden Y. S. (2010): Orta karadeniz bölgesi için geliştirilen kişniş (Coriandrum sativum L.) çesitlerinin bazı tarımsal özelliklerinin belirlenmesi, Verim ve Uçucu Yağ Oranının Stabilite Analizi. G.O.Ü. Ziraat Fak. Derg., 27 (1), 1-8.

[50] Wallace R. J., Mcewan N. R., Mcintosh F. M., Teferedegne B. Newbold C. J. (2002): Natural products as manipulators of rumen fermentation. Asian-Aust. J. Anim. Sci., 15 (10), 1458-1468.

[51] Wallace R. J. (2004): Antimicrobial properties of plant secondary metabolites. Proceedings of the Nutrition Society, 63, 621-629.

[52] Wanapat M., Pichad K., Pawadee P., Sadudee W. (2008): Effect of supplementation of garlic powder on rumen ecology and digestibility of nutrients in ruminants. $J$. of the Sci. of Food and Agriculture, 88 (13), 2231-2237.

[53] Wei-Lian H., Liu J., Jun-An Y.,Wu Y., Guo Q. (2000): Effect of tea saponin on rumen fermentation in vitro. Coordinated Research Projects from Joint FAO/IAEA Division, IAEA (Contract No. 12665/R0).

[54] Yeşilbağ D. (2007): Fitobiyotikler. Uludağ Unv. J. Fac. Vet. Med., 26 (1-2), 33-39. 